\title{
LSE
}

LSE ‘Europe in Question' Discussion Paper Series

\section{On Productivity Measurement and Interpretation: Some Insights on Italy in the European Context}

Roberta De Santis and Valeria Ferroni

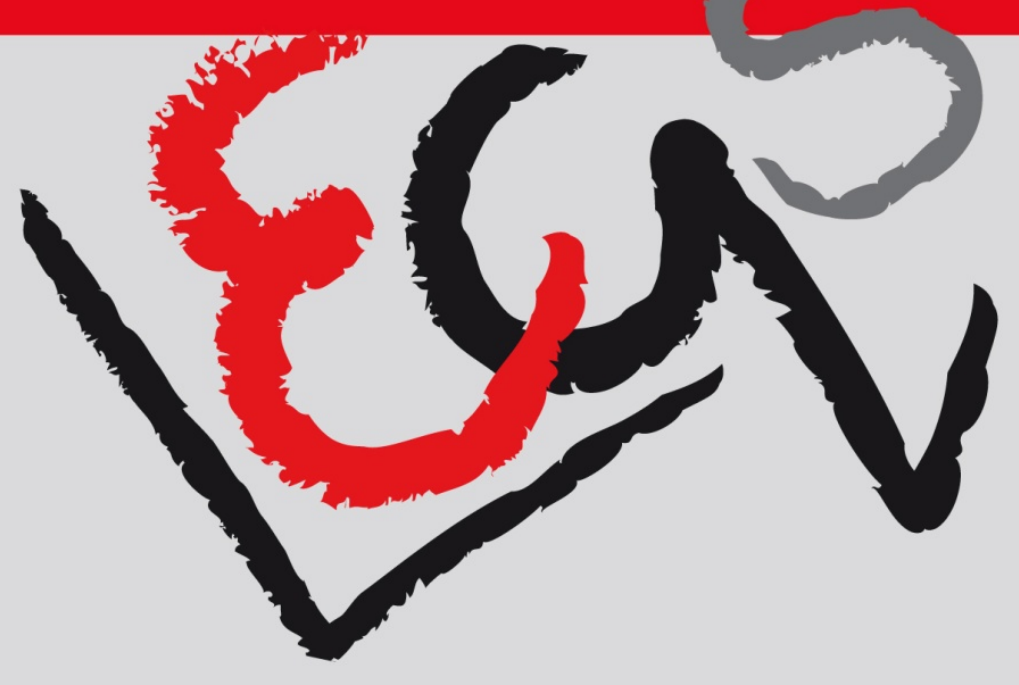




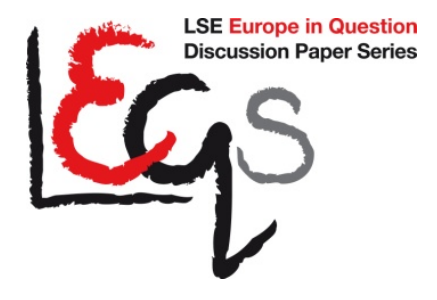

Editorial Board

Dr Bob Hancké

Dr Jonathan White

Dr Sonja Avlijas

Dr Miriam Sorace

Mr Sean Deel

All views expressed in this paper are those of the author and do not necessarily represent the views of the editors or the LSE.

(c) Roberta De Santis and Valeria Ferroni

Eqs 


\title{
On Productivity Measurement and Interpretation: Some Insights on Italy in the European Context
}

\author{
Roberta De Santis * and Valeria Ferroni **
}

\begin{abstract}
Over the period 1995-2016, the Italian performance in terms of productivity was poor in historical terms and in comparison with its main international partners. This issue goes beyond Italy, with declining productivity growth observed, from the second half of the nineties, in several other advanced economies. Possible explanations for the slowdown include factors such as lower capital investment by firms, decreased competition, excessive regulation, and capital misallocation. The diffuse slowing rates of measured productivity growth has also raised questions on whether GDP and output current compilation methods are adequate (i.e. the mis-measurement hypothesis). The "ICT revolution" has created new ways of exchanging and providing goods and services as result of increased connectivity. These developments challenge the way economic activity is traditionally measured. There are also measurement problems associated with estimating output and input volumes especially related to the quality of price indexes for some products and services. These problems have an impact on productivity estimates and might impair international comparability. In this paper, we intend to investigate what the core problems in productivity measurement and interpretation are in the European context, with a specific focus on Italy.
\end{abstract}

Keywords: Productivity, GDP, mismeasurement, prices, digitalization

JEL Codes: E1, E22, E24, E30

\footnotetext{
* Istat-Luiss

Email: rdesantis@istat.it

** Sogei SpA

Email:vferroni@sogei.it
} 


\section{Table of Contents}

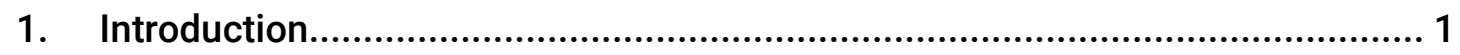

2. The productivity "puzzle" and the mismeasurement hypothesis ..................... 2

3. Some stylized facts on Italian productivity growth in the European context...... 6

4. Some insights on productivity measurement and interpretation for Italy ....... 14

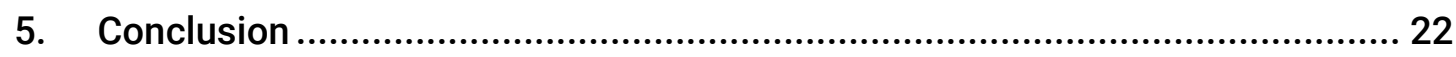

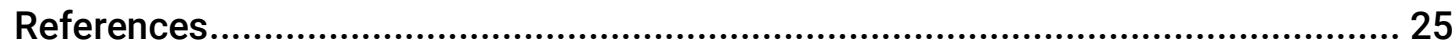

\section{Acknowledgments}

The views expressed in this paper are those of the authors and do not necessarily represent the institutions with which they are affiliated. Any errors or mistakes remain the authors' sole responsibility. Thanks are due to Sergio De Nardis, Francesco Nucci, Ottavio Ricchi and Paolo Savona and an anonymous referee for many helpful suggestions.

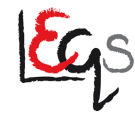




\section{On Productivity Measurement and Interpretation: Some Insights on Italy in the European Context}

\section{Introduction}

The generalized slowing rates of productivity growth in many advanced countries since the second half of the 1990s have stimulated a debate among economists and policy makers on the reasons for this decline in performance. Concerns are emerging that this might reflect a structural slowdown, and a new "low productivity growth" paradigm. Within this global trend, Italy stands out since its subdued productivity has been among the main causes of the gloomy GDP growth recorded in the last 20 years.

Possible explanations for the slowdown provided by the relevant literature include factors such as lower capital investment by firms, decreased competition, excessive regulation, and capital misallocation. The diffuse slowing rates of measured productivity growth has also raised questions on whether GDP and output current compilation methods are adequate (i.e. the mis-measurement hypothesis). The "ICT revolution" has created new ways of exchanging and providing goods and services as result of increased connectivity. These developments challenge the way economic activity is "traditionally" measured. There are, for example, measurement problems associated with estimating output and input volumes especially related to the quality of prices indexes for some products and services. These problems, that are transversal 
to all the possible explanations of productivity disappointing performance, have an impact on productivity estimates and might impair international comparability.

In this paper, after having surveyed the main determinants of the "productivity puzzle" provided by the recent literature, we focus on core problems in productivity measurement and interpretation for Italy at aggregate and sectoral level. Understanding the possible causes of Italian productivity mismeasurement and misinterpretation might help in designing policies better oriented towards fostering economic growth and the international competitiveness of domestic firms.

The paper is organized as follows: in the first section, we present a survey of recent empirical literature on the productivity deceleration determinants. In the second section, we describe the main stylized facts of productivity growth in the main European countries in the period 1995-2016, and in the third section we analyse the core problems in productivity measurement and interpretation for Italy in the European context. The conclusion follows.

\section{The productivity "puzzle" and the mismeasurement hypothesis}

As already mentioned, the literature provides several different explanations to the Italian productivity slowdown ${ }^{1}$. As effectively underlined by Bugamelli et al. (2018), to explain the Italian productivity "puzzle" it is necessary to consider all the alternative explanations/determinants "internal" (i.e. lack of innovation, skills mismatch of human capital, misallocation of talents and old age of managers) and “external" (i.e. capital misallocation, labour market, competition and regulation, insolvency regime and business environment) (Table 1).

${ }^{1}$ For an extensive survey see Bugamelli et al., 2018. 
The recent literature univocally suggests that the common limitation of many previous studies is that they focused on only one determinant. In this paper, we concentrate on the so-called mismeasurement hypothesis, which is the productivity slowdown explanation that has received relatively lower attention in the literature on Italy. Moreover, we believe that this explanation might be transversal to all the others.

Table 1. Main productivity deceleration determinants for Italy

\begin{tabular}{|c|c|c|}
\hline Determinants & Authors & Explanation \\
\hline $\begin{array}{l}\text { Sectoral } \\
\text { specialisation }\end{array}$ & Faini and Sapir (2005) & $\begin{array}{l}\text { Italian model of specialization is characterised by } \\
\text { traditional sectors with low human-capital intensity and } \\
\text { low technology. }\end{array}$ \\
\hline Firm size & $\begin{array}{l}\text { De Nardis (2014) } \\
\text { Barba-Navaretti et al. } \\
(2008)\end{array}$ & $\begin{array}{l}\text { Italian productive system is characterised by the } \\
\text { prevalence of SMEs, which display a lower level of } \\
\text { productivity when compared to large firms. }\end{array}$ \\
\hline \multirow{4}{*}{$\begin{array}{l}\text { Corporate } \\
\text { ownership and } \\
\text { management }\end{array}$} & Bugamelli et al., 2012 & $\begin{array}{l}\text { In Italy, the SMEs are mostly family firms and tend to be } \\
\text { controlled and closely managed by family members This } \\
\text { might be a source of misallocation of talents, if the most } \\
\text { appropriate managerial skills are not found within the } \\
\text { family owning the firm. }\end{array}$ \\
\hline & $\begin{array}{l}\text { Pellegrino and Zingales } \\
(2014)\end{array}$ & $\begin{array}{l}\text { Italian SMEs inability to cope with EMEs competition and } \\
\text { their failure of exploiting the ICT revolution due to the } \\
\text { lack of meritocracy in managerial selection and } \\
\text { promotion, as well as to familyism and cronyism. }\end{array}$ \\
\hline & $\begin{array}{l}\text { Daveri and Parisi (2010) } \\
\text { Daveri and Parisi (2015) }\end{array}$ & $\begin{array}{l}\text { Italy's productivity slowdown can be explained by } \\
\text { managerial age especially in innovative firms and to a } \\
1997 \text { labor market reform that liberalized temporary } \\
\text { employment contracts, which reduced firms' incentives } \\
\text { to invest in human capita }\end{array}$ \\
\hline & $\begin{array}{l}\text { Lippi and Schivardi } \\
\text { (2014) } \\
\text { Bandiera et al. (2014) }\end{array}$ & $\begin{array}{l}\text { Italian family firms tend to select their managers more } \\
\text { based on loyalty than capabilities and employ less } \\
\text { power-incentive remuneration schemes with respect to } \\
\text { other firms }\end{array}$ \\
\hline Skills mismatch & $\begin{array}{l}\text { OECD (2015) } \\
\text { Montanari et al. (2015) }\end{array}$ & $\begin{array}{l}\text { Italy is characterised both by a large share of under- } \\
\text { skilled and of over-skilled workers with respect to the } \\
\text { competencies required by their job. It seems also to be } \\
\text { the country in which a reduction of skill mismatch would } \\
\text { be associated with the highest increase in the allocative } \\
\text { efficiency with respect to the other European countries }\end{array}$ \\
\hline $\begin{array}{l}\text { Capital } \\
\text { misallocation }\end{array}$ & $\begin{array}{l}\text { Linarello and Petrella } \\
\text { (2017) }\end{array}$ & $\begin{array}{l}\text { The allocative efficiency is one of the major explanation } \\
\text { of the Italian gap, compared to its peers, in terms of } \\
\text { productivity growth }\end{array}$ \\
\hline $\begin{array}{l}\text { Mismeasurement } \\
\text { hypothesis }\end{array}$ & $\begin{array}{l}\text { Ahmad et al. (2017) } \\
\text { Giraud et al (2017) }\end{array}$ & $\begin{array}{l}\text { Bias determined in GDP and productivity indicators due } \\
\text { to potential ICT products price mis-measurement and } \\
\text { evidence of overestimation of price change in official } \\
\text { price indices for Italy }\end{array}$ \\
\hline
\end{tabular}


The productivity measurement as surveyed by Syverson (2011) has at least three areas with a specific need for additional research and development of data and methodology: i) price indices for output measures by industry; ii) measurement of hours worked by industry; iii) the quality of existing measures of capital input.

As data on output is mainly available in terms of the value of production, the data should be converted from value data to volume data. The influence of changes in price is usually removed through deflating by an appropriate price index ${ }^{2}$. Multifactor Productivity (MFP) and Labour productivity (LP) calculate industry output as real value added deflated by the relevant price index. However, price indices for output measures by industry, particularly for high-technology industries and economically relevant services (i.e. financial sector, health care and education) are difficult to measure. There are also many problems associated with the accurate measurement of hours worked, particularly when disaggregated by industry. Specific challenges in this context include a successful combination of information from the two main statistical sources, enterprise and household surveys, and the measurement of the labour input and the compensation of self-employed workers.

As output and input quality can change over time, improvements in quality should be quantified. In practice, statistical institutes are limited in the quality adjustments they can make, and the extent to which these fully adjust for quality is indeterminate.

Two main problems in measuring inputs that can introduce errors into the estimates of productivity are: i) difficulties in measuring the volume of capital services and ii) lags between investment when it is counted as adding to the productive capital stock and when it is utilized in production. These issues arise mainly where there are large infrastructure projects and when a major new technology is introduced. Investments

2 There is a considerable literature on the choice of an appropriate price index showing that the choice can significantly affect the estimates of productivity (Griliches 1991). 
in knowledge and in human capital therefore take years before they add to productive capacity.

From a statistical point of view, it emerges that it is difficult, using country-level data, to disentangle multiple potential causes of the productivity slowdown. For this reason, it is better to use sector-level and firm-level data. The advancement in research on productivity using micro data, mostly referred to firm data, has expanded further the field of analysis but it has been increasing also measurement and data quality problems. In this framework, as suggested by Syverson (2011) there are at least three additional main sets of measurement issues concerning respectively: i) output measure, ii) inputs measure and iii) aggregating multiple inputs in a MFP measure.

As for output measure, it is worth underlining that many businesses produce more than one output. It is not straightforward whether in this case the outputs should be aggregated to a single output measure and how. Even detailed microdata typically do not contain measures of output quantities.

Concerning the inputs measure, for labour there is the choice of whether to use number of employees, employee-hours or some quality-adjusted labour measure (i.e. wage bill), while capital is typically measured starting from the establishment or firm's book value of its capital stock. This kind of measurement raises several questions concerning i) the goodness of capital stock to proxy the flow of capital services, ii) the measurement of capital stock by the producer's reported book value, and the choice of deflators, iii) the measurement of capital stock using observed investments and the perpetual inventory method and the assumption about depreciation.

It is worth noting that input measurement choices should be considered carefully since any output driven by unmeasured input variations due, for example, to input quality differences or intangible capital will be considered as productivity. As for the multiple inputs aggregation in a MFP measure, it should be noted that MFP differences reflect shifts in output while holding inputs constant. To construct the output-input ratio that 
measures MFP, it is necessary to weight the individual inputs appropriately when constructing a single-dimensional input index.

\section{Some stylized facts on Italian productivity growth in the European context}

In contrast to the 1970s and 1980s, when it was the best growth performer among its major European partners, Italy has suffered a steady and prolonged productivity stagnation since the 1990s. In the context of the recent global financial crisis, the legacy of this fall has arguably made the Italian recession deeper and more persistent than in many other advanced economies. In what follows, we intend to underline major stylized facts related to Italian productivity trends.

Stylized fact 1. Regardless of the metric chosen to measure productivity, Italian productivity growth has stagnated over the last 20 years. Italian labour productivity growth has been low, both in historical terms and compared to European partners ${ }^{3}$. Figure 1 shows that after the crisis the level of Italian labour productivity showed a temporary reduction. This trend was generalized across European partners with few exceptions (e.g. Spain). In the aftermath of the crisis, however the other main European countries showed a rebound that cannot be found in the Italian data.

\footnotetext{
${ }^{3}$ Given some differences in the observation sample used by the various countries, the international comparison is biased by some discrepancies.
} 
Figure 1.

Labour productivity in EU countries: 1995-2016

(index 1995=100, real labour productivity per hours worked)

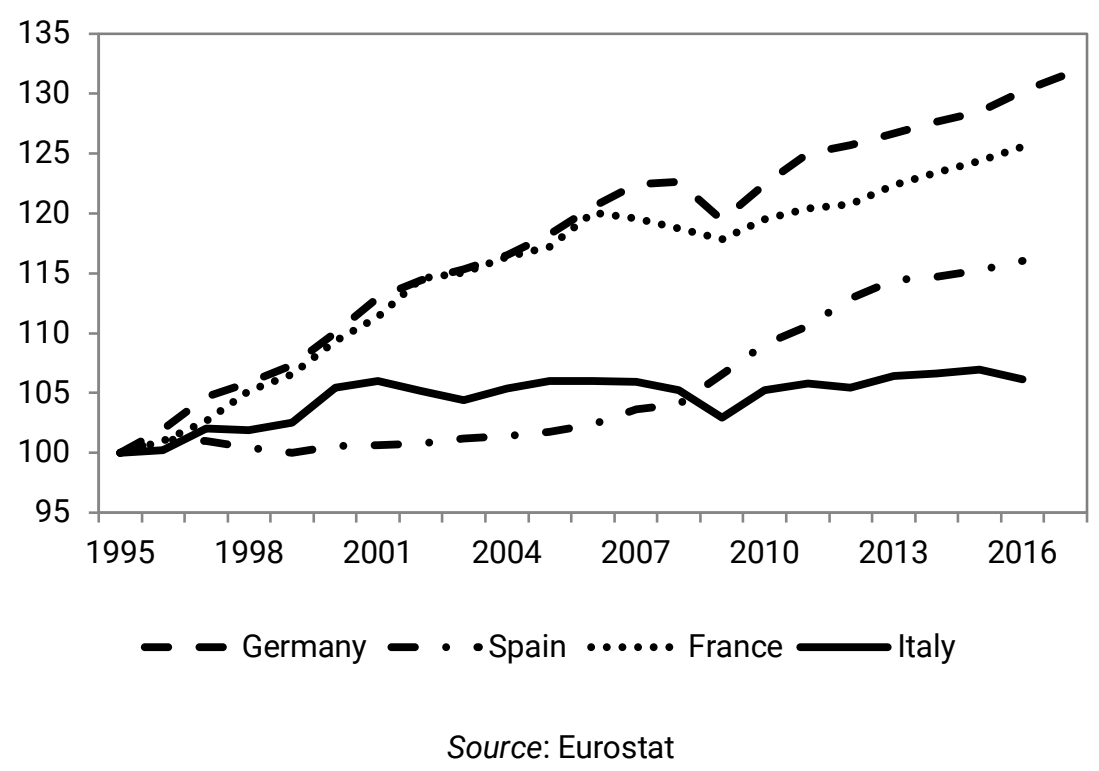

In Italy, over the entire period 1995-2016, the average annual growth rate in value added was $0.6 \%$. Labour productivity rose by $0.3 \%$ due to labour inputs increasing by less than the growth in value added. The growth in labour productivity in 1995-2016 was driven only by capital deepening, which contributed for 0.4 percentage points, with total factor productivity contributing for -0.1 percentage points. Non-ICT capital contributed for 0.2 percentage points, while ICT capital (e.g. computer hardware, communications equipment and computer software) accounted for 0.1 percentage points. In the same period, capital input (1.4\%) and the combined inputs of capital and labour $(0.7 \%)$ rose more than value added and both capital productivity and total factor productivity fell (respectively $-0.9 \%$ and $-0.1 \%)^{4}$.

We divide the entire period into three sub-periods: i) the pre-crisis period (1995-2007); ii) the two crises period (2008-2013); and iii) the recovery period (in Italy from 2014). Before the crisis, labour productivity growth was slightly positive while MFP growth was null on average. During the crisis, all the indicators showed a decline in

${ }^{4}$ Istat, Productivity Measures, November 2017 https://www.istat.it/en/archivio/213752 
productivity growth. Since the recovery, productivity showed a slow recovery in MFP growth while labour productivity growth measured by hours worked was slightly negative. Figure 2 decomposes the rate of labour productivity growth into drivers of capital deepening (i.e. the rate at which the capital-labour ratio is increased) and of MFP for the three sub periods mentioned above.

\section{Figure 2.}

\section{Decomposition of labour productivity growth}

(percentage points and \% change)

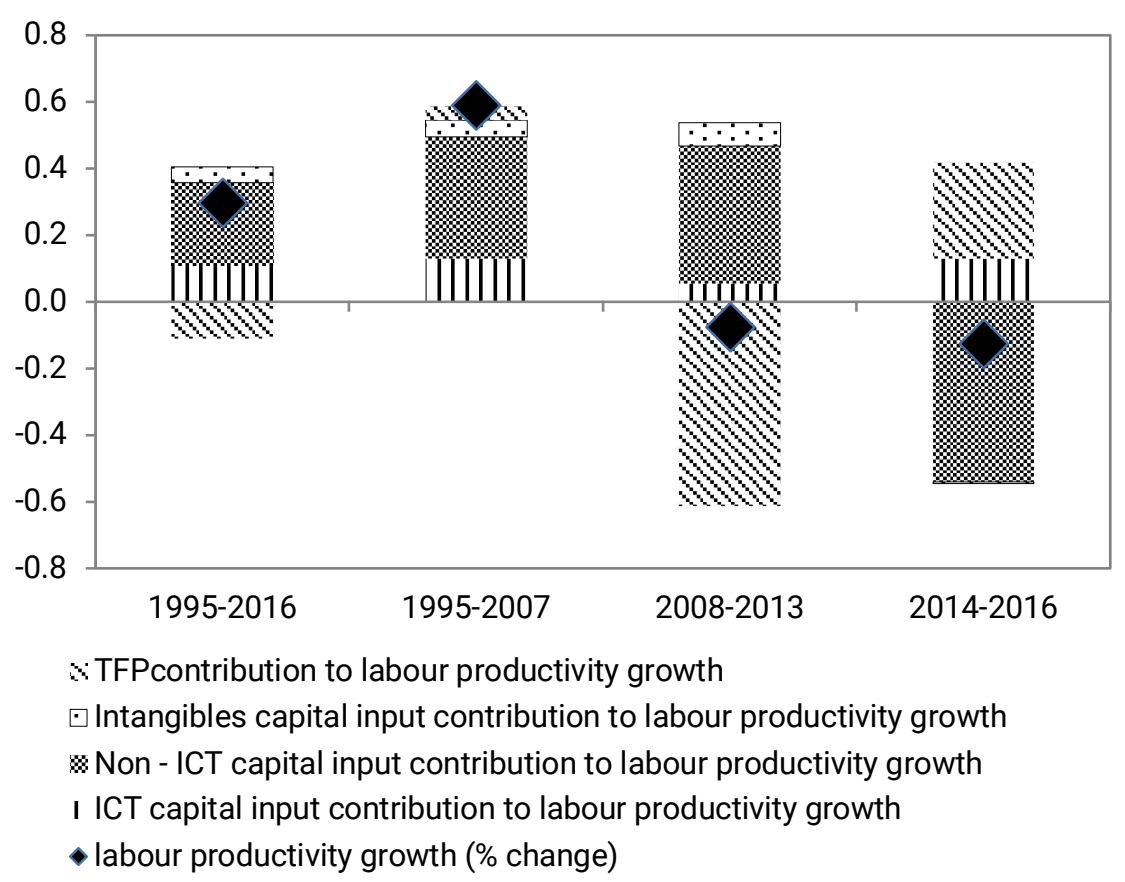

Source: Istat

The period after the global financial crisis in 2008 shows overall the decline in labour productivity growth to be driven by a sharp reduction in the underlying rate of MFP growth. Over the 2008-13 period, capital deepening gave a very positive contribution as result of significant shedding of labour during the crisis period and in particular during the period 2008-09. Eventually, the analysis of the data available for the 
recovery period (2014-2016) indicate a negative capital deepening and a positive contribution of the MFP5 .

In Germany and France in the same period, the average annual growth rate in labour productivity was respectively $1.3 \%$ and $1.1 \%$. As is evident in Figure 3 , the composition is definitely different compared to Italy. The growth in labour productivity in 1995-2016 was driven mainly by total factor productivity with a positive contribution coming from ICT and non-ICT capital deepening.

Using the same three sub-period division, it is also worth noting that during the crisis German MFP contributed positively to labour productivity growth while this was not the case for France. On the contrary, non-ICT capital deepening contribution was slightly negative in Germany in the post-crisis period while it has been always positive in France.

\section{Figure 3.}

Decomposition of labour productivity growth in France and Germany

(percentage points and \% change)
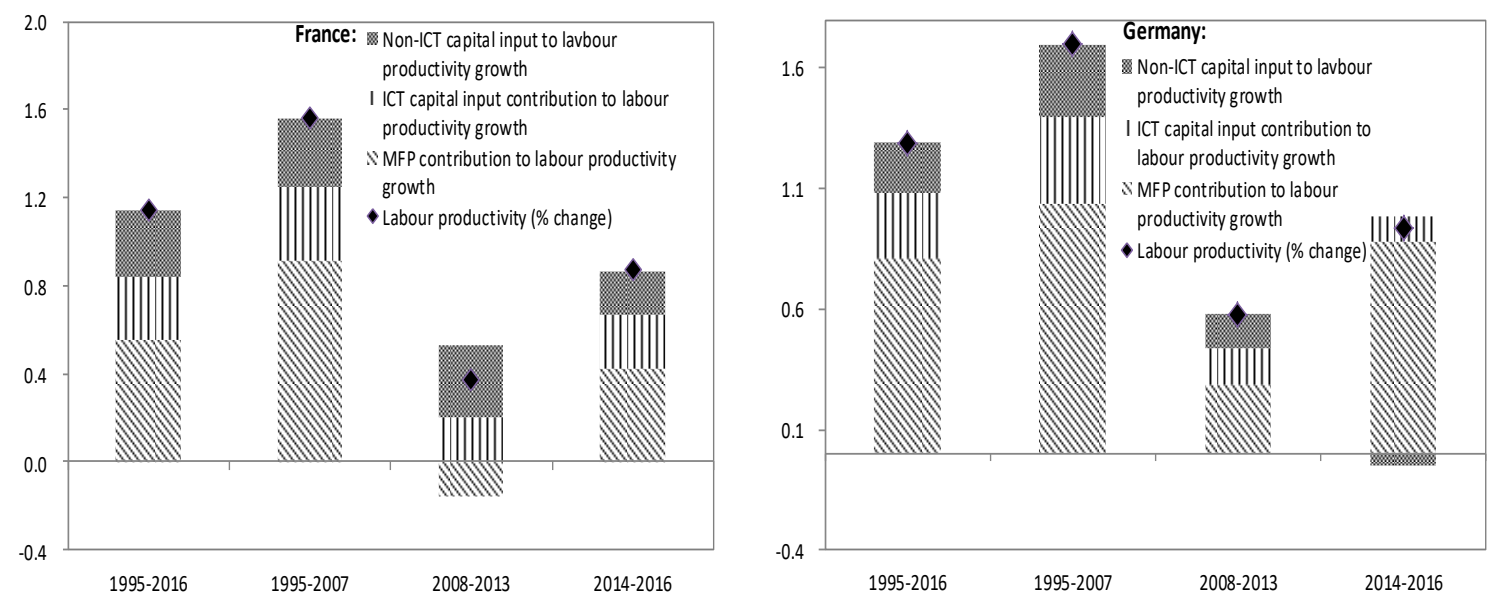

Source: Eurostat

\footnotetext{
${ }^{5}$ It is worth noting that 2016 data are still an estimate and will be revised further in the coming
} months. 
Stylized fact 2. Since 2009, the decline in labour productivity is due to both a marked reduction in MFP growth and, since 2014, the absence of capital deepening. Over the longer term, the slowdown in MFP growth seems to have been the key contributor to the slowdown in labour productivity growth in Italy since the mid-1990s. In fact, MFP growth in the main advanced economies has decelerated significantly since the crisis. ${ }^{6}$

In Italy, the slowdown in capital deepening since 2014 reflects both a strong drop of gross fixed investment and a recovery in employment growth. Investment growth rates were on average negative since the beginning of the crisis and started to gradually recover in 2015-2016 but at a lower rate with respect to pre-crisis rates. However, the decline in capital deepening since 2014 also reflects a marked offsetting effect arising from growth in employment, which has been relatively strong compared to the rebound in economic activity. This effect has contained the rate of capital deepening and, in fact, fully offset the low (albeit now modestly expanding) rate of investment growth since $2015^{7}$.

${ }^{6}$ A common hypothesis to explain part of the slowdown is increasing mismeasurement, particularly associated with the "free" goods provided by IT firms like Google and Facebook (Ahmad et al., 2017).

${ }^{7}$ Capital deepening refers to the process of increasing the capital-labour ratio by giving labour more capital to work with. However, the capital-labour ratio may also indicate "artificial" capital deepening in periods of low net investment if significant shedding of labour mechanically increases the ratio of the existing net capital stock to a reduced workforce. During the depths of the crisis, Italy saw some support to capital deepening - and, indeed, a slight increase in the rate of capital deepening-mainly as result of heavy shedding of labour in some sectors (which mechanically supported capital deepening, notwithstanding markedly reduced net investment). 
Figure 4.

Multi-factor productivity trends in industrialized countries

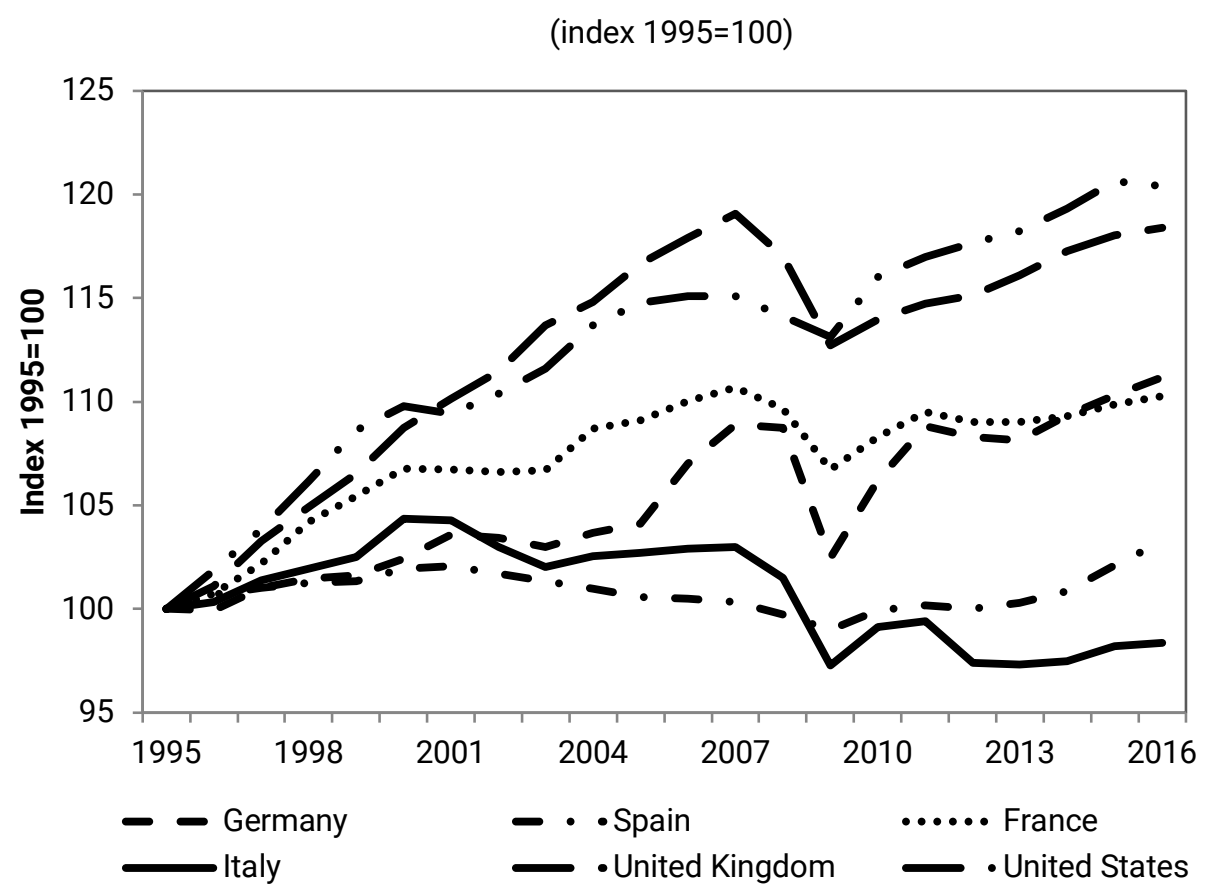

Source: AMECO Database, European Commission

Many reasons have been put forward to explain the negative trend in capital deepening since 2013. These include: i) the strong concentration of the recovery in consumer-driven sectors where growth is heavily concentrated in those services that are the most labour-intensive and in which the potential for capital-labour substitution remains limited, coupled with a persisting weakness in investment in construction and ii) the impact of the global financial crisis and ongoing credit constraints in its aftermath. These elements are likely to help explain the low rates of capital deepening seen over the period of recovery ${ }^{8}$.

According to recent studies in progress based on firm level data', the rate of capital depreciation due to technological obsolescence is on average $5 \%$ per year in Italy. The

\footnotetext{
8 The results of the analysis for Italy are line with the ones found by ECB (2017).

${ }_{9}^{9}$ Bank of Italy, Economic Bulletin, July 2017.
} 
strong reduction in investment amid the economic crisis led not only to a decrease in installed capacity, but also caused it to become less technologically updated. In a growth accounting exercise, results show that the poor growth of productivity during the crisis was principally due to the stagnating investments.

Stylized fact 3. In Italy, at the sectoral level, weak labour productivity is not widespread but mostly concentrated in services while different results are found for the euro area as a whole. The pattern of weak labour productivity growth at the sectoral level can be seen using a more detailed sector breakdown. The long-term trend towards services as an evergreater proportion of the total economy might be expected to result in a reduction in aggregate labour productivity growth, as productivity growth in these sectors is typically lower than in other (mainly industrial) sectors. It is worth emphasising, however, as mentioned in Section 1, that, the measurement problems for the services sectors are greater than those for the manufacturing sector.

As shown in Figure 5, some sectors (i.e. services subsectors) show falls (often significant) in average rates of labour productivity growth between the two periods (see the sectors to the right of the $45^{\circ}$ line) while in the manufacturing sectors there has been an improvement. Some subsectors of manufacturing improved their performance after the crisis, such as textiles, wood and paper, rubber and plastic or food and beverages products, while pharmaceutical products which outperformed before and after the crisis.

The construction sector recorded the same annual average in both periods. Figure 5 clearly shows that the Italian productivity problem is mostly related to the negative performance of services, particularly professional activities. Wholesale and insurance and financial activities did not improve their position after the crisis while communication and information services and transportation and storage decreased their productivity after the crisis. 
Figure 5.

Pre- and post-crisis labour productivity growth by sectors

(average annual \% changes)

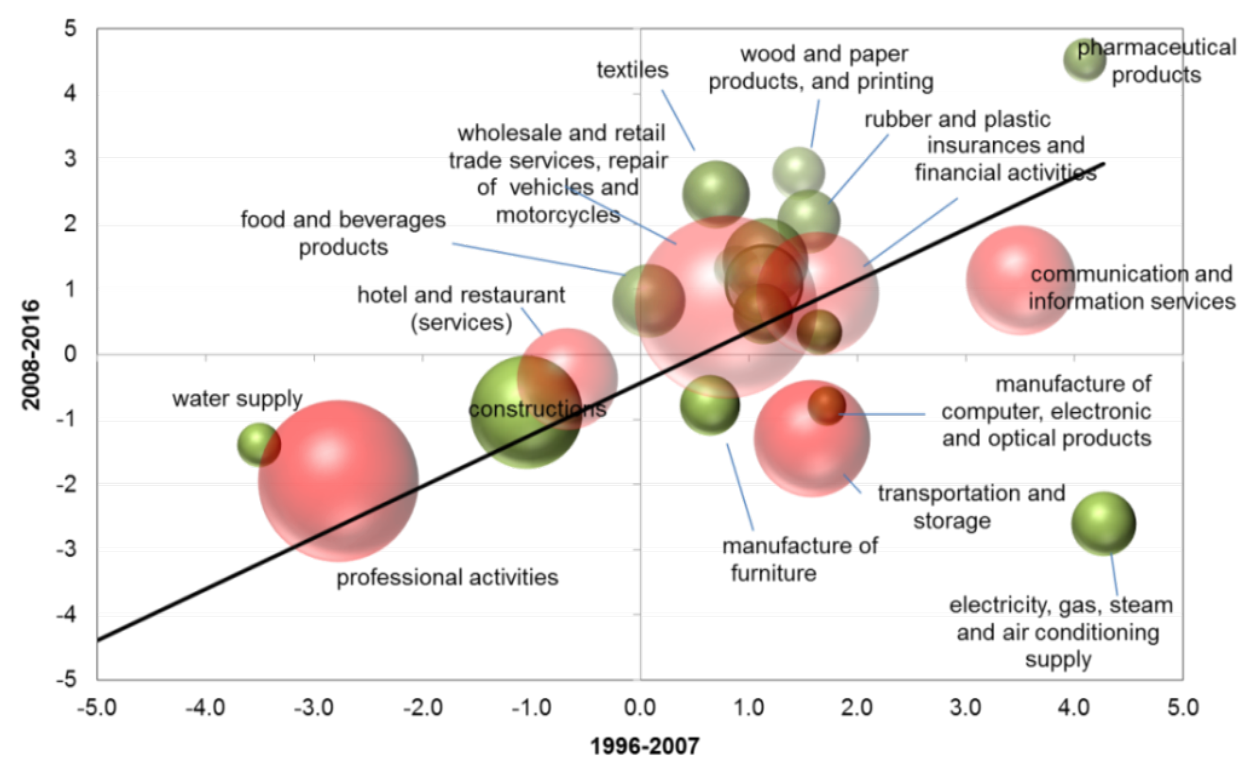

Source: Authors' calculations based on Istat data

Note: labour productivity is defined as value added per hours worked. Colours refer to: industrial sub sectors (green) and services (red); bubbles size reflect the share of each sector on value added in 2016; sectors on the $45^{\circ}$ line are those in which the pre- crisis and post-crisis period average are equal.

By contrast, according to a recent ECB report ${ }^{10}$, "the decline in euro area labour productivity growth is widespread at the sector level, reflecting a marked slowdown in within-sector rates, rather than a shift in industrial structure towards sectors with low labour productivity". Furthermore, other analyses show falls (often significant) in average rates of labour productivity growth between the two periods (pre- and post2013) particularly in the manufacturing sectors and the more traded market services (such as wholesale trade, financial and insurance services, legal and managerial services, and travel-related services).

${ }^{10}$ ECB (2017), The slowdown in euro area productivity in a global context", ECB, Economic Bulletin, Issue 3. 


\section{Some insights on productivity measurement and interpretation for Italy}

In line with what was discussed in Section 1, it is worth underlining that there are some significant problems in productivity measurement and interpretation that should be carefully considered when analysing productivity trends. These include, for measurement primarily: i) the heterogeneity in international compilation methods and ii) the measurement of information and communications technology (ICT)- related goods and services. Concerning the interpretation of productivity data, there are at least three features that should be examined in studies on Italian productivity: i) recent peculiar behaviour of data revisions, ii) the heterogeneity across firms within sectors and across sectors and iii) the data aggregation.

Regarding the productivity compilation methods, it is worth noting that there is not a mandatory common international regulatory framework not even for EU members. Countries mostly follow the OECD manual methodology but several discrepancies in productivity measurement across EU countries remain, especially concerning the service sector. In Figure 6, it is possible to notice differences among the labour productivity indicators for Italy provided by various sources. 
Figure 6.

Labour productivity measures among different sources

(index 2010=100)

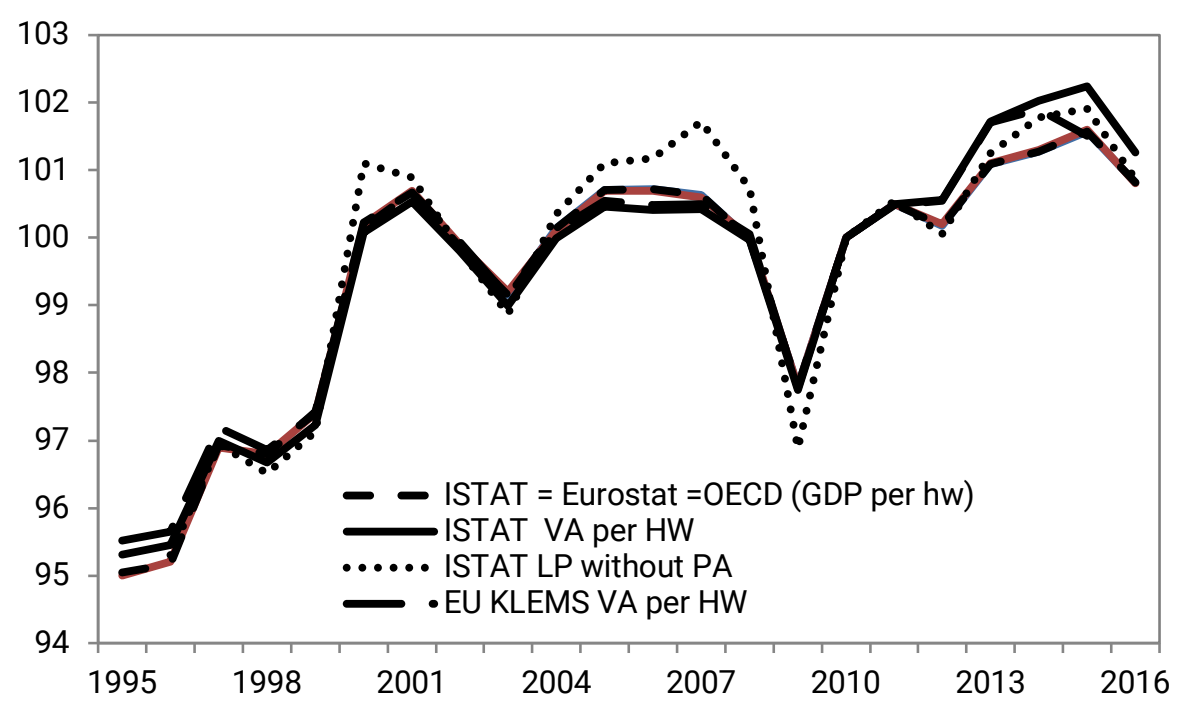

Sources: OECD, Eurostat, EU KLEMS and Istat

Labour productivity indexes, measured in GDP per hours worked, are the same for OECD, Istat and Eurostat while there are some minor differences between Istat and EU KLEMS for the productivity measured on value added per hours worked. This difference can be related to the revisions of the national accounts which occurred in September after the release of EU Klems update. A more volatile path of labour productivity is traced by the measure of labour productivity, which excludes the Public Administration sector. In Italy, the adopted methodology by Istat closely follows the approach outlined in the OECD Manual on Productivity Measurement. ${ }^{11}$

11 "Output is the chain linked valued added at basic prices. Labour input is measured as total hours worked by all persons engaged in production. Capital input is measured as the volume of capital services provided by the stocks of three categories of ICT assets, eight categories of tangible non-ICT assets and three categories of intangible non-ICT assets. Productivity measures are estimated using national accounts data released in accordance with NACE Rev.2 classification. Estimates are provided for 38 industries, as well as for the total economy. Both industry level and aggregate estimates are calculated net of real estate activities, of activities of 
In this framework, the EU KLEMS project aims to create a common database on measures of economic growth, productivity, employment creation, capital formation and technological change at the industry level for all EU members from 1970 onwards. The project attempts to overcome current deficiencies in official industry level statistics, especially concerning data for service industries. The achievements of the project are promising, but more efforts are needed to overcome the heterogeneity in productivity measurement.

Concerning the measurement of information and communications technology (ICT), in Italy the contribution of intangible capital to labour productivity growth has been rather limited, with a particularly small contribution from spending on research and development. Italian companies have a lower propensity to innovate than their main European competitors, especially in connection with the adoption of ICT technologies ${ }^{12}$. Part of this difference, however, might be also due to measurement issues. Inadequate measurement of both intangible investments and improvements in the quality of ICT-related goods and services may bias estimates of outputs and inputs and result in misleading conclusions regarding labour productivity and MFP growth.

Efforts to ease these problems are ongoing but still inconclusive and contain: i) concerted efforts aimed at creating better measures of "intangible assets" in national accounts data sources via the inclusion of "intellectual property products" in the European System of National and Regional Accounts (ESA 2010); ii) attempts to reassess the development of ICT-based prices.

As for the first point, in the new version of the Italian national accounts, according to the ESA 2010 and thus in line with all the European countries, Research and

households, of activities of extraterritorial organizations and of all activities of the General government sector. In the benchmark year 2011 the total of the above defined sectors accounted for $70.4 \%$ of total value added and $83.0 \%$ of total hours worked" (Istat 2017). Concerns on capital measurement arise if we consider the impact of technological progress on capital obsolescence. Until now, this issue is not considered in the national accounts (OECD, 2009).

12 See De Santis, Ferroni, Jona Lasinio (2017). 
Development expenses are considered as an investment since they contribute to the accumulation of production capacity through intangible capital; in the past, these were recorded as current expenditure. Currently, the main international organizations (i.e. OECD, Eurostat, European Commission) are exploring the possibility of expanding the inclusion of intangible asset in the European System of National Accounts ${ }^{13}$.

As for the second point, the inadequate adjustment for quality change that affect the distinction between price and volume changes when estimating growth of output and capital inputs that we discussed above is particularly relevant for ICT products. The latter tend to undergo frequent changes in quality and specifications. When technological progress is rapid, standard methods may undervalue the quality of improvements embodied in new models, leading to overestimation of the growth of quality-adjusted prices and underestimation of output volume growth. Recent studies finding evidence of overestimation of price change in official price indices for ICT and software have revived the discussion of price mismeasurement ${ }^{14}$.

On this issue, a recent paper by Ahmad et al. (2017) provides a simple first indication of the possible scale of price mismeasurement constructed by comparing measured price changes across countries for three kinds of products: ICT equipment, software and databases, and communications services. Many of the differences across countries in the measured price change since the second half of the 1990s are substantial. To illustrate the potential scale of mismeasurement, prices of computers and telecommunications equipment show little change over the past two decades in Spain, and declines of between 70 and 90\% in Australia, Canada, Germany, the Netherlands, UK, and the US. In Italy and Austria, prices fall by only around $20 \%$ over the past two decades but remain broadly flat in the second decade ${ }^{15}$.

\footnotetext{
${ }^{13}$ See Byrne and Corrado (2017).

${ }^{14}$ See, Ahmad et al. (2017), De Loecker, and Goldberg (2014).

${ }^{15}$ The large differences in price movements for software also point to different index construction and quality adjustment procedures.
} 
Ahmad et al. (2017) provides various attempts to measure the bias determined in GDP and productivity indicators due to potential ICT products price mis-measurement, and Italy ranks among the countries whose measurements are more severely biased. At the European level, despite some progress, the harmonization of personal consumption expenditure deflator compilation methodology is still incomplete. For example, Giraud et al. (2017) find evidence of overestimation of price changes in official price indices for Italy accounting for about 0.2 percentage points of the GDP differences between Italy and France.

Regarding the interpretation of productivity data, the Italian productive structure presents some peculiarities that require a closer look. As underlined in the previous paragraph, there is a heterogeneous performance in terms of productivity across sectors. The main culprit for productivity weakness seems to be the service sector, while the manufacturing sector proved, on average, to be resilient and at least as dynamic as its main European peers.

Manufacturing productivity showed, since 2010, a greater acceleration than in France and Spain thanks to substantial structural adjustments "carried over by firms which reallocated resources to the most efficient companies; the crisis contributed to select the entry and the survival in the market of more competitive firms and to increase R\&D intensity" (Bugamelli et al 2018).

Despite the fact that, by definition, statistical revisions should provide errors that on average are null, Italian national accounts revisions ${ }^{16}$ since 2012 have been showing a peculiar pattern for the manufacturing sector (see Figure 7).

\footnotetext{
16 National statistics institutes are committed to releasing annual national accounts (and their revisions) twice a year (at the beginning of March and end of September) which are compliant with the definitions of the European System of Accounts (ESA 2010) and Council Regulation (EC) n. 549/2013.
} 
Indeed, since 2003, productivity measured as value added on hours worked in the manufacturing sector has been growing steadily, ${ }^{17}$ and starting from 2012 Q1 revisions to national accounts showed a better picture with every new release. Major revisions occurred to the manufacturing sector value added (numerator) more than on the hours worked (denominator).

Figure 7.

Revisions in labour productivity

(manufacturing sector, value added/ hours worked \%)

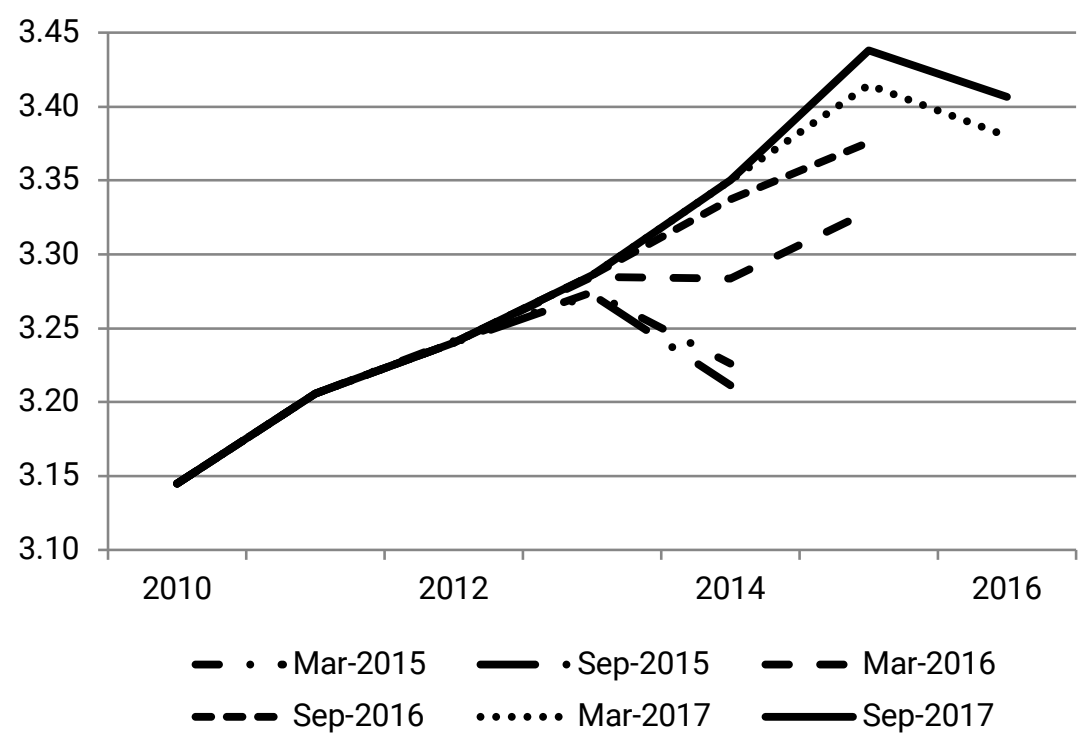

Source: Istat (2017)

Another aspect that needs to be investigated is the heterogeneity across firms within each sector. In fact, Italy is the country with the most fragmented and polarized productive system if compared to other EU economies ${ }^{18}$. For example, the

\footnotetext{
${ }^{17}$ It increased by $1.6 \%$ per year on average between 2003 and 2007 and accelerated to $1.9 \%$ after 2009.

${ }^{18}$ In Italy microenterprises, i.e. those with less than 10 employees, account for $95 \%$ of the total number of firms and for $29 \%$ of total value added. On the other tail of the distribution, large
} 
manufacturing sector is characterized by a high degree of heterogeneity in performance (Figure 8).

Figure 8.

Gross value added per employee - manufacturing

(Thousands of euro, number of employed person)

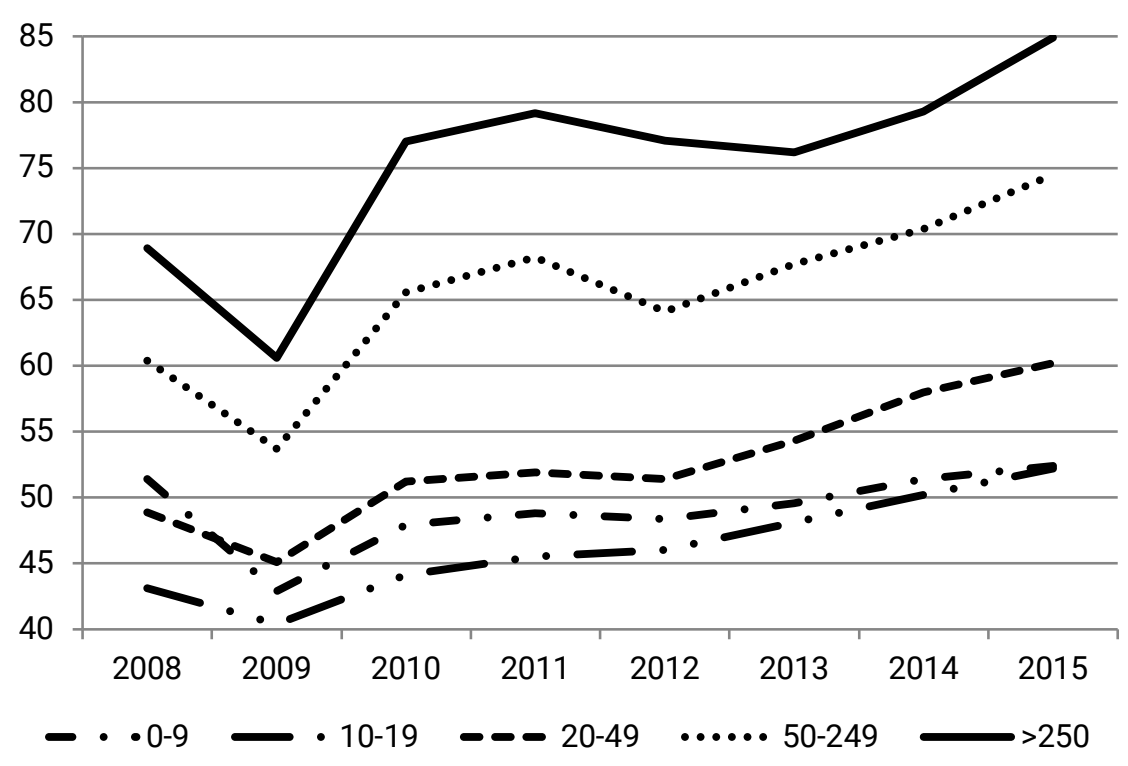

Source: Structural Business Statistics Eurostat

Productivity growth of the top $10 \%$ firms, in the post crisis period, not only dominated that of the median firm and that of the bottom $10 \%$, but it also steadily increased. This result supports the idea that the most efficient part of the Italian productive system, after the crisis, has been showing important recovery signals in terms of productivity in the manufacturing sector and that the main culprit of productivity stagnation most likely is the services sector.

companies, with more than 250 employees, do not reach $0.1 \%$ in terms of number of firms, against $0.5 \%$ and $0.2 \%$ in Germany and France, respectively. 
The relevant literature (Bugamelli et al., 2012) indicates that the Italian productive system is essentially formed by two main groups: i) a smaller group of medium and large-sized firms, which are efficient. Their performance and strategies are linked to innovation, technology and exports are in line with the main European countries and ii) a bigger group of micro firms, which, on the contrary, have a low propensity to innovate and compete on global market. These firms are characterized also by a vulnerable financial structure. The firms belonging to the first group have been able to react to the financial crisis. By contrast, the micro firms were hit hard by the financial and sovereign debt crisis and by the effects of globalization.

In Figure 9, there is evidence that labour productivity was higher in Italy than in Germany, France and Spain when considering medium and large firms (from 50 to 249 employees $)^{19}$.

Figure 9.

Gross value added per employee - manufacturing

(thousand euro, 50-249 employees)

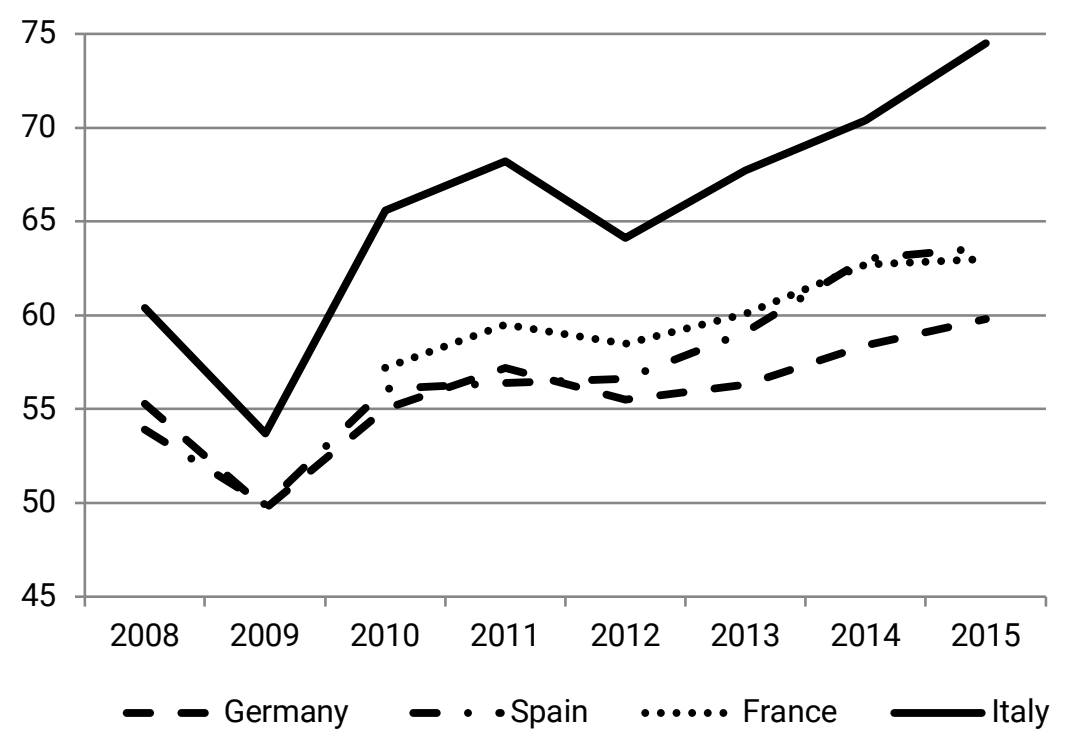

Source: Structural Business Statistics Eurostat

19 See also DeNardis (2014) 
Another interpretation argument that requires attention is the role of data aggregation that seems to be not neutral in the Italian productivity performance measurement.

There is a growing literature on the role of allocative efficiency of resources as a determinant of productivity growth and, in this contest, recent empirical works find that the allocative efficiency is one of the major explanations of the Italian gap, compared to its peers, in terms of productivity growth. Linarello and Petrella's (2017) evidence of improved allocative efficiency before the crisis when analysing the universe of Italian firms rather than a smaller subsample stands in contrast with other papers $^{20}$. Their results depend primarily on their sample selection.

The non-neutrality of data aggregation is underlined also by recent studies in progress by the Bank of Italy on potential output growth using a production function approach applied to Italian individual firm level data. Preliminary results show that the relationships between inputs and outputs existing at firm level are preserved under aggregation only if some restrictive conditions hold ${ }^{21}$. Where these conditions do not hold, the methodologies based on micro data seems to be more effective in capturing some events such as the misallocation of inputs.

\section{Conclusion}

The weak performance since the 1990s of productivity at the global level intensified the research on this issue. Among the many possible determinants identified by the literature, questions were raised on the adequacy of current compilation methods. The relevant studies evidenced several productivity measurement problems associated with estimating output and input volumes especially related to the quality of prices

\footnotetext{
${ }^{20}$ Linarello and Petrella (2017)'s evidence of improved allocative efficiency before the crisis is in contrast with other works which use the methodology developed by Hsieh and Klenow (2009) based on the idea that misallocation increases with the degree of dispersion in measured TFP and subsamples of incorporated firms.

${ }^{21}$ For example when a production function is homogeneous of degree one and there are no frictions in the accumulation and disposal of inputs
} 
indexes for some products and services. These problems might have had an impact on productivity estimates and consequently have impaired the international comparisons evidences.

In this paper, we have suggested that, despite their not being a major cause of Italian productivity weak performance, there are some methodological and interpretation issues that need to be addressed to evaluate productivity trends properly.

Specifically, we see the absence at the international level of a fully common shared methodology to compile productivity statistics and to adjust data for quality change as a major shortcoming. The latter problem substantially affects the distinction between price and volume changes when estimating growth of output and capital inputs. It also impairs the international comparison at the European level.

Moreover, although some progresses has been achieved in the System of National Accounts (SNA 2010), incomplete measurement of both intangible investments and quality of ICT-related goods and services still determines biased estimates of outputs and inputs and might result in misleading conclusions regarding labour productivity and MFP growth.

Specifically for Italy, we have underlined that there are factors that might have biased the interpretation of productivity evidence. In fact, the recent peculiar 'behaviour' of data revisions, at least for the manufacturing sector, suggests that, once more information is included, the performance of productivity seems to improve. This evidence needs to be further investigated.

There are also signals that the higher heterogeneity across firms (within and between sectors) in Italy compared to other European countries makes aggregate measures of productivity less suitable for international comparisons. Recent empirical papers have underlined that the presence of aggregation bias might have led to mismeasurement of productivity trends in several empirical analyses on Italian productivity behaviour. 
This preliminary findings suggest that some advancement in the harmonization of productivity measurement also at European Union level are required to better understand the different causes of productivity deceleration and to design better policies oriented towards fostering economic growth and competitiveness. 


\section{References}

Ahmad, N., J. Ribarsky and M. Reinsdorf (2017), "Can potential mismeasurement of the digital economy explain the post-crisis slowdown in GDP and productivity growth?" OECD Statistics Working Papers, 2017/09.

Banca d'Italia, (2017), Economic Bulletin, July

Bandiera O., Lemos R., Prat A.and R. Sadun. (2017), "Managing the Family Firm: Evidence from CEOs at Work" NBER Working Paper No. 19722

Barba Navaretti, G., Faini R. and A. Tucci, (2008), “Does Family Control Affect Trade Performance? Evidence for Italian Firms," CEPR Discussion Papers 7082, C.E.P.R. Discussion Papers.

Byrne, D. and C. Corrado (2017), "ICT prices and ICT services: What do they tell us about productivity and technology?", Finance and Economics Discussion Series, No. 2017-015, Board of Governors of the Federal Reserve System.

Bugamelli M., L. Cannari, F. Lotti and S. Magri (2012), The innovation gap of Italy's production system: roots and possible solutions, QEF Occasional Papers, n. 121, Bank of Italy.

Bugamelli M., F. Lotti, M. Amici, E. Ciapanna, F. Colonna, F. D'Amuri, S. Giacomelli, A. Linarello, F. Manaresi, G. Palumbo, F. Scoccianti, E. Sette (2018), Productivity growth in Italy: a tale of a slow-motion change" QEF n. 422 Bank of Italy.

Daveri, F., Parisi, M., (2010) Experience, Innovation and Productivity - Empirical Evidence from Italy's Slowdown CESifo Working Paper Series No. 3123

Daveri, F., Parisi, M., (2015) “Experience, Innovation and Productivity: Empirical Evidence from Italy's slowdown", Industrial and Labor Relations Review, 889-915

De Loecker J and P. K. Goldberg (2014), Firm performance in a global market, Annual Reviews, vol. 6(1), pages 201-227, August

De Nardis S. (2014), Efficienza e specializzazione, Scenario Nomisma

De Santis R., Ferroni V. and C. Jona Lasinio (2017) "Investment in innovation and the Italian productivity slowdown: an industry perspective", Economic Focus n.1, Dep. Of Treasury, MEF.

ECB (2017), The slowdown in euro area productivity in a global context", ECB, Economic Bulletin, Issue 3..

Faini, R. and A. Sapir, (2005) Un modello obsoleto? Crescita e specializzazione dell'economia italiana. 
Giraud C. J. and B. Quévat (2017) Pourquoi la croissance de l'Italie a-t-elle décroché depuis 2000 comparée à la France, Insee Note de conjoncture

Hsieh C. and P. J. Klenow, (2009). "Misallocation and Manufacturing TFP in China and India," The Quarterly Journal of Economics, Oxford University Press, vol. 124(4), pages 1403-1448. Istat (2017), Productivity measures, report.

Lippi, F., Schivardi, F., (2014) "Corporate Control and Executive Selection", Quantitative Economics, Vol. 5, pp. 417-456, 2014.

Linarello A. and A. Petrella, (2017) "Productivity and Reallocation: Evidence from the Universe of Italian Firms", International Productivity Monitor, n.31.

Montanari, M., D. Pinelli and R. Torre (2015) “From tertiary education to work in Italy: A difficult transition", ECFIN Country Focus 12(5), June.

OECD, (2009), Measuring capital,

OECD (2015) Economic Survey of Italy.

OECD (2015) The future of productivity book.

Pellegrino, B., Zingales, L., (2017) Diagnosing The Italian Disease, NBER Working Papers.

Syverson C., 2011. “What Determines Productivity?,” Journal of Economic Literature, American Economic Association, vol. 49(2), pages 326-365, June. 


\section{Recent LEQS papers}

Avlijaš, Sonja. 'The dynamism of the new economy: Non-standard employment and access to social security in EU-28' LEQS Paper No. 141, February 2019

Besimi, Fatmir \& Monastiriotis, Vassilis. 'The Role of EU Integration in Accelerating Structural Reforms in the Western Balkans: Evidence, Theory and Policy' LEQS Paper No. 140, January 2019

Saka, Orkun \& Bircan, Çağatay. 'Lending Cycles and Real Outcomes: Costs of Political Misalignment' LEQS Paper No. 139, December 2018

Wolkenstein, Fabio. 'Transnational Partisanship and Networked Constituent Power in the EU' LEQS Paper No. 138, October 2018

Macchiarelli, Corrado 'What is the EU-UK relation all about? Tracking the path from monetary integration to "ever closeness"' LEQS Paper No. 137, September 2018

Meyer, Niclas 'EU break-up? Mapping plausible pathways into alternative futures' LEQS Paper No. 136, August 2018

Di Cataldo, Marco \& Monastiriotis, Vassilis 'An assessment of EU Cohesion Policy in the UK regions: direct effects and the dividend of targeting' LEQS Paper No. 135, June 2018

Innes, Abby 'First-best-world economic theory and the second-best-world of public sector outsourcing: the reinvention of the Soviet Kombinat by other means' LEQS Paper No. 134, May 2018

Bojar, Abel 'With a Little Help from My Friends: Ministerial Alignment and Public Spending Composition in Parliamentary Democracies' LEQS Paper No. 133, April 2018

Voss, Dustin "The Political Economy of European Populism: Labour Market Dualisation and Protest Voting in Germany and Spain" LEQS Paper No. 132, March 2018

Campos, Nauro F. \& Macchiarelli, Corrado "Symmetry and Convergence in Monetary Unions" LEQS Paper No. 131, March 2018

Costa Font, Joan \& Perdikis, Laurie 'Varieties of Health Care Devolution: "Systems or Federacies"?' LEQS Paper No. 130, February 2018

Calrsson, Ulrika “The Perennial Thirty Years' War” LEQS Paper No. 129, February 2018

Isiksel, Turkuler "Square peg, round hole: Why the EU can't fix identity politics" LEQS Paper No. 128, January 2018

Hancké, Robert \& Vlandas, Tim “The Politics of Disinflation” LEQS Paper No. 127, December 2017

White, Jonathan "Between Rules and Discretion: Thoughts on Ordo-liberalism" LEQS Paper No. 126, November 2017

Costa Font, Joan \& Zigante, Valentina "Building 'Implicit Partnerships'? Financial Long Term Care Entitlements in Europe" LEQS Paper No. 125, October 2017 


\section{LEQS}

European Institute London School of Economics Houghton Street WC2A 2AE London Email: euroinst.LEQS@Ise.ac.uk

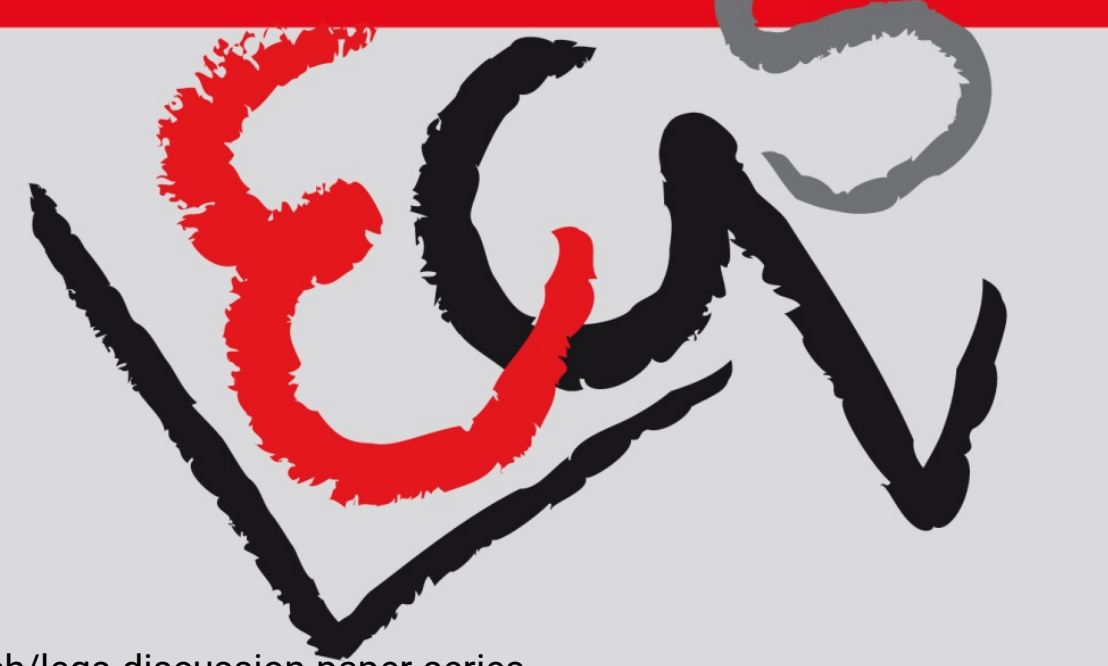

